MTA BTK Filozófiai Intézet

\title{
Világátlépések: hogyan kondicionálja a cselekvési tér a társadalomtudományos magyarázatokat
}

A társadalomtudomány aspirációi között elókeló helyet foglalnak el olyan szempontok és célkitúzések, melyek valamennyi tudományos igénnyel fellépố vizsgálódás alapvetó mozgatórugójának számitanak: a valóság egy bizonyos szegmensének intelligibilissé tétele, valamint jelenségeinek magyarázata. ${ }^{1}$ Amennyiben azt várjuk el társadalomtudományainktól, hogy a társadalmi jelenségek közötti valós összefüggések érvényes magyarázataival szolgáljanak, úgy a tudománymetodológiai vitákat az elmúlt két évszázadban tematizáló megértés és magyarázat problémájával találjuk szembe magunkat. Ha a társadalomtudományok az általuk vizsgált jelenségek közötti valós összefüggésekról kívánnak számot adni, úgy elkerülhetetlen,

hogy megértsék, interpretálják azokat - ha pedig érvényes magyarázatokkal szeretnének szolgálni, meggyózóen kell tudniuk érvelni amellett, hogy módszereik valóban alkalmasak azoknak a problémáknak a kezelésére, melyekre alkalmazzák óket.

A szélsóségesen interpretatív és radikálisan szcientista társadalomtudomány-koncepciók kivételével a két meghatározó fogalom általában együttesen van jelen a társadalomtudományok filozófiai megalapozását megkísérló müvekben, pusztán a hangsúlyok tolódhatnak el egyik vagy másik irányba. Az alábbi

fejtegetésekben Manicas (2006) meglátásait követve azzal a feltételezéssel élek, hogy megértés és magyarázat kölcsönösen kiegészitik egymást, azaz a társadalmi jelenségek elemzó leírása és interpretációja elósegitheti azok múködési módjainak és hatásainak magyarázatát - a magyarázataink pedig újraértelmezéseket tesznek lehetốvé.

A megértés, az interpretáció fontos komponense a társadalomtudományok módszertani eszköztárának: ahhoz, hogy valamilyen tömegmegmozdulást forradalomként vagy ünnepként értékeljünk, majd magyarázatot adjunk okairól és következményeiről, szükséges azt előzetesen valamilyen interpretációs keretben értelmeznünk. Az azonban rendkívül lényeges, hogy ténylegesen milyen interpretációs kerettel dolgozunk - mivel bizonyos szempontok figyelembevétele vagy figyelmen kívül hagyása torzíthatja percepci- 
ónkat, befolyásolva ezzel a későbbi magyarázatok jellegét is. A következőkben amellett kívánok érvelni, hogy a társadalomtudományos interpretáció meghatározó mértékben függ a vizsgált társadalom fogalmiságától, az abban a specifikus közegben értelmezhető cselekvési módoktól és személy-típusoktól. Amennyiben egy magyarázat-javaslat úgy kíván bizonyos jelenségekről számot adni, hogy ezekre a korlátokra nincs tekintettel, úgy annak érvényessége joggal vonható kétségbe, akármekkora adattömeggel és bármennyire finomhangolt elemzési eszköztárral dolgozzanak is a kutatók a magyarázatuk alátámasztása érdekében.

\section{Mit magyaráz a társadalomtudomány?}

Mielőtt az interpretáció természetéről és társadalmi jelenségekkel kapcsolatos sajátosságairól szó esne, fontos körülhatárolni, hogy egyáltalán milyen típusú jelenségeket interpretálnak a társadalomtudományok. A tudományok általában létezők bizonyos típusairól kívánnak érvényes és megbízható magyarázatokat adni: a természettudományok természeti törvényeiket általában fajtákra, az ún. természeti fajtákra fogalmazzák meg. ${ }^{2}$ A társadalomtudományok ennek megfelelően a társadalmi jelenségekkel, a „társadalmi fajtákkal" foglalkoznak: azok kialakulását, fennmaradását, esetleges változásait magyarázzák, valamint számos esetben ezeknek a változásoknak az elörejelzését is feladatuknak tekintik. A társadalmi fajta ('social kind') vagy az emberi fajta ('human kind') terminusok nem tekintenek vissza a természeti fajtákéhoz hasonlóan hosszú múltra: a tudományfilozófiai diskurzusban csak a múlt század nyolcvanas évei óta használatosak. Mivel a továbbiakban a „társadalmi fajta” kategóriája kulcsszerepet kap az érvelésben, érdemes megvizsgálni, hogy található-e olyan differentia specifica, amely alkalmas lehet arra, hogy elkülönítse társadalmi fajtáinkat a természeti fajtáktól. Amennyiben kimutatható ilyen minőségi különbség közöttük, az a társadalomtudományos interpretációk érvényességére vonatkozóan is lényeges következményekkel járhat.

A társadalmi fajták jellemzőit vizsgálva azt találhatjuk, hogy azok több olyan tulajdonsággal is rendelkeznek, melyekkel nem kell számolnunk a természeti fajták esetében. Bhaskar (1979, 37-48. o.) három, míg Wendt (1999, 69-71. o.) négy sajátosságot említ: 1. A társadalmi fajták térben és időben is specifikusak, létük meghatározott helyhez és időszakhoz kötött.

2. A társadalmi fajták fogalmi természetüek: nem pusztán a megfigyelésük, de a kialakulásuk is függ annak a társadalomnak a fogalmiságától, melyben létrejönnek.

3. A társadalmi fajtákat emberi cselekedetek tartják fenn: aktív ágensek tevékenysége nélkül nem érdemes létező társadalmi fajtákról beszélni.

4. A társadalmi fajták kívülről (a társadalmi struktúra felől) meghatározottak: a különböző társadalmi szerepek csak más szerepekhez képest definiálhatók (pl. nem lehet valaki tanár anélkül, hogy a szerep birtokosát a definícióban a diákhoz képest pozicionálnánk) (Bhaskar, 1979, 37-48.; Wendt, 1999, 69, 71.).

Kérdés, hogy mennyiben tekinthetők ezek a tulajdonságok a társadalmi fajták szükséges és elégséges feltételeinek. A térbeli és időbeli meghatározottság (1) önmagában nem tünik sem szükséges, sem elégséges feltételnek: számos természeti fajta szintén csak meghatározott területen jöhet létre (elég itt azokra a biológiai fajokra gondolni, amelyek evolúciós szempontból előnyös tulajdonságaikat kizárólag abban a környezetben alakíthatták ki, amelyben azok a sikeres adaptáció szempontjából elengedhetetlenek voltak), és ahogyan az ipari forradalom is csak bizonyos időszakban jellemezte az érintett társadalmakat, úgy például a dinoszauruszok is csak egy adott periódusban éltek a Földön. A másik három jellegzetesség viszont egyaránt abból következik, hogy a társadalmi fajták nem függetlenek attól a közösségtől, melyben létrejönnek: csak valamilyen 
értelem-tulajdonítás és annak megfelelő társadalmi gyakorlat hozhatja létre és tarthatja fenn őket. A mesterséges létrehozás és fenntartás kritériuma (3) sem lesz azonban elégséges feltétel, hiszen a természeti fajták között is találhatunk olyanokat, melyek emberi beavatkozástól függetlenül nem jöttek volna létre (ilyenek például azok a kémiai elemek és izotópok, melyek a kutatói laboratóriumokban keletkeznek, vagy a különböző biológiai fajták keresztezésével létrehozott növény- és állatfajok). ${ }^{3}$ Ezzel kapcsolatban érdemes megjegyezni, hogy az „emberi beavatkozástól függetlenül nem jöttek volna létre” kitétel nem egyenértékü azzal, hogy anélkül nem is jöhettek volna létre. Teljességgel elképzelhetőek olyan természeti törvények, amelyek mellett például a fermium fellelhető lenne a természetben - olyan természeti törvényekről viszont értelmetlen volna beszélni, amelyek mellett a „házasság” vagy a „pénz” kategóriája fordulna elő természetes módon.

A fogalmi természet (2) ezzel szemben olyan sajátosságnak tünik, mely alkalmas lehet arra, hogy elhatárolja a társadalmi fajtákat a természetiektől. A fenti felsorolás második pontjában megfogalmazott állításhoz kapcsolódva azt mondhatjuk, hogy egy jelenség akkor tekinthető a társadalmi fajták közé tartozónak, ha legalább részben azáltal létezik (és lehet tudományos vizsgálódás tárgya), hogy fogalmat alkotunk róla. Ez a jellegzetesség motiválja Hacking (Hacking (1986), 222. o.) megjegyzését is az emberrel és társadalommal foglalkozó tudományok tevékenységéről: „Tudományaink néha olyan embereket alkotnak meg, melyek addig egy bizonyos értelemben nem léteztek." Azaz a természettudományokkal szemben a társadalomtudományos kutatás nem feltétlenül kizárólag olyan jelenségekkel foglalkozik, melyek a kutatói tevékenységtől függetlenül is hozzáférhetőek voltak, hanem olyanokkal is, melyek azáltal váltak egyáltalán jelenségekké, hogy fogalmat alkottunk róluk. Ez a megállapítás nem egyenértékü azzal, hogy a természettudományok is klasszifikálják az általuk vizsgált jelenségeket, és hogy ez a klasszifikáció nem egyértelműen az emberi beavatkozástól függetlenül létező természeti fajták közötti „határvonalak” megtalálását jelenti. ${ }^{4}$

A különböző, társadalmi viszonyokat leíró fogalmaink természetéből következik az is, hogy azokat a legtöbb esetben a társadalmi struktúrából kiindulva értelmezhetjük (4). Ez természetesen annak köszönhető, hogy a társadalmi szerepek létrejötte eleve fogalmi kapcsolatokra épül: ahhoz, hogy rendelkezhessünk az „úr” fogalmával, szükségszerűen rendelkeznünk kell a „szolga” fogalmával is. Egyiküket sem tudjuk definiálni a másik figyelembe vétele nélkül, ez azonban fogalmi természetük egyik sajátossága, azaz összhangban van azzal a megállapítással, hogy a társadalmi fajtákat a természeti fajtáktól elhatároló különbség azok viszonya az őket leíró fogalmainkhoz. ${ }^{5}$ Társadalmi fajta-fogalmaink létrehozzák referenciájukat, és ezzel új nyelvhasználatot, valamint új társadalmi viszonyokat is keletkeztetnek. Összességében azt mondhatjuk tehát, hogy a társadalmi fajták természetiektől történő elkülönítésének szükséges és elégséges feltétele a következő: az adott fajta fennállását meghatározza, hogy rendelkezünk-e a fogalmával vagy sem. Ez a kritérium anélkül különbözteti meg a sajátosan emberi jelenségeket a természetiektől, hogy utalást tartalmazna olyan, számos további problémát felvető terminusokra, mint a ,jelentés” vagy a „reprezentáció” - ugyanakkor alkalmas arra, hogy az emberi tevékenységek által létrehozott természeti fajtákat (mint például a fent említett fermiumot) ne sorolja be a társadalmiak körébe.

Ezen a ponton azonban szükséges egy újabb megkülönböztetést tennünk. Számos társadalomtudomány ugyanis olyan jelenségeket vizsgál, amelyek fogalmával a társadalom tagjai az esetek döntő többségében nem rendelkeznek. A közgazdaságtani vizsgálódások során rendszeresen alkalmazott kategóriák (határhaszon, likviditás-preferencia stb.) számos példát szolgáltatnak erre vonatkozóan, de említhetnénk akár szociológiai vagy szociálpszichológiai fogalmakat is (anómia, in-group attitüd stb.). Amennyiben mindezeket a fentiek alapján kívánjuk értelmezni, felmerülhet a kérdés, hogy hogyan tudhatnak a társadalomtudományok olyan fogalmakkal kapcsolatban informatív elméleteket megfo- 
galmazni, amelyekkel a vizsgált populáció tagjai nem rendelkeznek. Nem tünik ugyanis értelmezhetetlennek közösségünkben a határhaszon elméletének megfogalmazása, és amennyiben valaki nem is tudná, hogy mit is jelent az valójában, egy rövid ismertetés után valószínűleg alkalmazhatónak gondolná azt saját viselkedésével kapcsolatban is. Ez pedig ellentmondani látszik annak, hogy a társadalmi fajták fennállásához szükséges, hogy rendelkezzünk fogalmukkal.

Kicsit közelebbről szemügyre véve azonban azt találhatjuk, hogy az ellentmondásosság feloldható, amennyiben megkülönböztetjük egymástól a társadalmi és a társadalomtudományos fajtákat. Ez utóbbiakat az különíti el a hétköznapok során használt társadalmi fajtáktól, hogy létrejöttük egy, a társadalmi valóság tudományos igényü tanulmányozását végző csoport, azaz a társadalomtudomány müvelőinek tevékenységéhez kötődik. Ebből a szempontból érvényesnek tarthatjuk a Putnam (1975, 145-146. o.) által javasolt „nyelvi munkamegosztás” tézisét: ugyanúgy nem szükséges a társadalom nagy részének tisztában lennie a likviditás-preferencia fogalmával, ahogyan az alumíniumot sem muszáj tudniuk megkülönböztetni a molibdéntől. Ez ugyanis a „,szakértők” (esetünkben a társadalomtudomány müvelőinek) feladata, a hétköznapi világ cselekvői pedig semmivel sem lesznek kevésbé képesek eligazodni világukban, ha nem ismerik a tudományos terminológiát. A természettudományos hasonlóságok azonban ezen a ponton véget érnek, hiszen például a molibdénről tett kijelentéseink igazsága nem függ bizonyos társadalmi intézmények meglététől, a társadalomtudományos fajták azonban előfeltételezik egyéb társadalmi fajták fennállását az adott társadalomban.

A határhaszon mint társadalomtudományos fajta a neoklasszikus közgazdaságtan egyik univerzálisan alkalmazható elméletének kulcsfogalma, és alkalmazásával olyan kultúrák preferenciáiról is számot tudunk adni, amelyek akár még a „közgazdaságtan” fogalmával sincsenek tisztában. Tisztában kell legyenek azonban olyan fogalmakkal, amelyek alkalmassá teszik közgazdaságtani elméleteinket arra, hogy látszólag teljesen idegen kontextusban is magyarázóerővel bírjanak. Ismerniük kell tehát olyan fogalmakat, amelyek rendkívül hasonlóak a magyarázat alapját képező áru, ár, kereskedelem vagy érték fogalmakhoz. Ahol ezek a fogalmak teljes mértékben hiányoznak a hétköznapi élet menetéből, ott értelmetlenek maradnak az ezeken alapuló társadalomtudományos fajták segítségével adott magyarázatok is. Elképzelhetünk például egy közösséget, ahol a javak cseréje (amelyet ők egészen biztosan nem így hívnának) kizárólag teljesen véletlenszerűen választott tárgyak ajándékozására korlátozódik. Tárgyak ugyan léteznek ebben a társadalomban is, azonban ára egyiknek sincsen, nem is értelmezhetőek árukként, a társadalom tagjai pedig az ajándékozást nem tekintik kereskedelemnek, és nem is kapcsolnak csereértéket a tárgyaikhoz. Egy ilyen társadalomról sok minden elmondható (például az is, hogy hosszú távon valószínüleg nem lesz életképes), azonban a határhaszon elmélete segítségével nem adhatnánk érvényes magyarázatot az ilyen keretek között élő emberek vásárlási és fogyasztási szokásaira. Azaz társadalomtudományos fajtáink meglétéhez nem szükséges, hogy mint a társadalom tagjai, mindannyian rendelkezzünk velük és használjuk öket hétköznapjaink során - azokkal a fogalmakkal azonban rendelkeznünk kell, amelyekre a társadalomtudomány kategóriái „ráépülnek”.

A társadalomtudományok ennek alapján olyan létezőkkel foglakoznak saját fajtáik kialakítása során, amelyek fogalmiságunknak köszönhetik létüket, és amelyek, mint azt Hacking kapcsán láthattuk, bizonyos értelemben nem léteztek azelött, hogy fogalmat alkottunk volna róluk. Amikor társadalomtudományos magyarázatokat kívánunk adni bizonyos, bennünket érdeklő társadalmi jelenségekkel kapcsolatos kérdésekre, olyan típusú jelenségeket kell tehát interpretálnunk, amelyek bizonyos értelemben nem léteztek a fogalomalkotás előtt. Joggal merülhet fel a kérdés, hogy mit is jelent valójában ez a „,bizonyos értelemben” kitétel, és mennyiben támaszthat korlátokat a társadalomtudományos interpretációkkal szemben. 


\section{Mi is az, amit interpretálunk?}

A társadalmi intézmények, szokások, folyamatok nem abban az értelemben részei a világnak, ahogy a fizikai tárgyak és élölények azok. Kategóriarendszereink, melyek segítségével a sajátosan emberi tevékenység által létrehozott jelenségeket értelmezzük, számos esetben ugyanezen jelenségek létrejöttében szerepet játszó instrumentumok is egyben. Amikor egy társadalmi jelenséget magyarázni igyekszünk, leírást adunk bizonyos cselekvésekről - interpretálunk bizonyos viselkedésmintákat. Az, hogy a rendelkezésünkre álló leírások milyen készletéből válogathatunk, egyben azt is meghatározza, hogy milyen cselekvésekről és milyen típusú cselekvőkről alkothatunk egyáltalán képet. A pszichiátriai betegségek kategóriái jó példával szolgálnak erre Hacking vizsgálódásaiban, a kategóriák és kategorizáltak viszonyára azonban már Michel Foucault is rávilágított. A bünügyi eljárások és az állami büntetésvégrehajtás mechanizmusait elemezve a következőket írja:

„A pszichiátriai szakértelem, de még általánosabban a bünügyi antropológia és a kriminológia [...] egyik funkciója éppen ez: azáltal, hogy a tudományos tudás tárgyaivá tehető dolgok körébe beemelik a büncselekményeket, az ítéletvégrehajtást nem pusztán a kihágások természetével kapcsolatban ruházzák fel igazolható hatalommal, hanem az individuumokkal kapcsolatban is; nem is pusztán csak azzal kapcsolatban, hogy mit is tesznek ezek az individuumok, hanem azzal is, hogy mik is ezek az individuumok, és mivé válhatnak." (Foucault, (1979), 18. o.)

Ez a gondolatmenet az alapja Hacking (1995a, 1998) példáinak is, melyekben a többszörösen összetett személyiség pszichiátriai kategóriáját vizsgálja, de megemlíthető még Arnold Davidson (1990) perverzekről szóló tanulmánya is, amely szintén valamilyen személy-kategória kialakulását és intézményes elterjedését elemzi. A példák egyaránt arra világítanak rá, hogy bizonyos társadalmi közegben bizonyos viselkedési módokat eltérően értelmezhetünk attól függően, hogy létezik-e a besorolásukhoz használt kategória vagy sem. Ahogyan Hacking fogalmaz, a cselekvésekről adható leírások nem pusztán a cselekvést magát, hanem a cselekvőt is meghatározzák - azaz annak módjait hozzák létre, ahogyan az adott közösségben egyáltalán személynek lehet lenni.

A társadalomtudományos magyarázatok számos olyan „emberi fajtát” és tevékenységi fajtát írnak le (és hoznak is létre ezáltal), melyek az általuk interpretált ágensek hétköznapi kategorizációitól eltérnek, ám a tudományos szférából leszivárogva befolyásolhatják azokat. Ehhez azonban arra van szükség, hogy az újonnan létrehozott kategóriák és a kategorizáltak között interakció jöhessen létre - azaz múködjön az a visszacsatolási mechanizmus, amely alapján Hacking (1995a) „interaktív fajtáknak” is nevezi az emberi fajtákat. A természeti jelenségektől eltérően a humán tudományok tárgyai maguk is tudatában lehetnek annak, hogy milyen kategóriarendszer segítségével írják le őket, azaz hogy milyen emberi fajtába tartoznak. Ezeket a fajtákat (azaz ezeket a személyiség-lehetőségeket) pedig elfogadhatják, elutasíthatják, vagy megkísérelhetik azokat megváltoztatni. A többszörösen összetett személyiségként kategorizáltak példája mindhárom lehetőségre rávilágít: az azonosulás és a tiltakozás mellett megfigyelhető, hogy a tudomány által ebbe a kategóriába sorolt emberek igyekeznek megváltoztatni a róluk kialakított képet - akár azáltal, hogy speciális klubokat alapítanak, akár pedig internetes oldalak létrehozásával. ${ }^{6}$ Ezt a fajta visszacsatolást nevezte Hacking (1995b) „,hurkoló-hatásnak" ('looping effect'), amely szintén olyan sajátossága a társadalmi fajtáknak, mellyel a természeti fajták nem rendelkeznek, és nem is rendelkezhetnek. Mindebböl viszont következik, hogy az interaktív fajták jelen idejüek, azaz érvényességük nem terjed ki olyan periódusokra, amelyekben az általuk jellemzett emberekkel lehetetlen lenne 
interakcióba lépniük. Azaz a többszörösen összetett személyiség fogalmának létrejötte és pszichiátriai szakkifejezéssé válásának megtörténte előtt a szó szoros értelmében nem létezhettek ilyen személyek - ahogyan perverzek sem lehettek azelött, hogy a szót jelenlegi értelmében definiálták volna. Ez természetesen nem jelenti azt, hogy ne lettek volna emberek, akiknek a viselkedése olyan jellegzetességeket mutatott, amelyeket a kriminológiai vagy a pszichiátriai szótárunk ma a „többszörösen összetett személyiség” vagy a „perverz” kategóriájának feleltetne meg. A fogalmak hiánya pusztán annyit jelent, hogy illegitim olyan terminusokban értelmezni bizonyos cselekvéseket, amelyek azok megtörténtekor nem álltak az adott társadalom tagjainak rendelkezésére. Foucault megjegyzései a büntetőjogi kategóriák „személykonstituáló” erejéről jellegzetesen a hatalmi mechanizmusok dinamikájának kritikai megvilágítását is céljukul tűzik ki - a tanulság azonban társadalomkritikai elköteleződés nélkül is általánosítható. Társadalomtudományos leírásaink egyben konstitúciós folyamatok is, az általuk leírt és interpretált cselekvések létrehoznak olyan jelenségeket, amelyek ebben az értelemben nem léteztek korábban: nem voltak fogalmi eszköztárunk részei, nem azonosíthattuk őket akként, amikként az újonnan bevezetett kategóriarendszerek alapján megtehetjük.

Ennek értelmében azt is helytelen lenne állítani, hogy bizonyos következmények, melyek az új kategóriarendszerek fogalmi természetéből fakadnak, okságiak lennének. Ahogy Hacking (1995a, 82. o.) megjegyzi a többszörösen összetett személyiség kialakulásának feltételezett okaival kapcsolatban:

„Megfigyelhetö, hogy egyesek a) hajlamosak a többszörösen összetett személyiség fogalmát a kora gyermekkori trauma terminusaiban definiálni, valamint b) azt állítani, mintha az egy felfedezés volna, hogy a többszörös személyiséget a gyermekkori trauma okozza. Nem kellene önmagunkat becsapva azt gondolnunk, hogy elöször definiáltuk a betegséget, majd felfedeztük az okát.”

Miután a többszörösen összetett személyiség (általánosan használatban lévő) fogalmából következik, hogy gyermekkori traumához köthetö, nem közlünk új információt azzal, ha ezt elismételjük, immár oksági magyarázat formájába bújtatva. Hasonló logikát követ a társadalomtudományos magyarázatok nagy része: a befektetési hajlandóság visszaesését a bizalom hiányával magyarázva például könnyen abba a hibába eshetünk, hogy a két fogalmat egymás terminusaiban határozzuk meg. Ez azonban fogalmi kapcsolatot implikál, azaz értelmetlen lenne azt állítani, hogy valaki hajlandó befektetni bizonyos üzletbe anélkül, hogy azt is állítanánk, hogy megbízik a neki ajánlatot tevőkben. ${ }^{7}$ A konceptualizáció folyamata, melynek során a társadalomtudományok az általuk vizsgálni kívánt jelenségeket definiálják, konstitúciós folyamat is egyúttal: a meghatározások sok esetben megalkotják a vizsgálandó jelenségek fogalmait, elemzésükkel pedig azokról a fogalmi kapcsolatokról is számot adhatunk, amelyeket a definíciók implikálnak. ${ }^{8}$ Ezek a kapcsolatok pedig épp annyira nem szolgálhatnak oksági magyarázatok alapjául, amennyire a hackingi példában szereplö pszichiátriai fogalom sem alkalmas erre. Nem szükséges azonban kizárólag szigorú értelemben vett oksági magyarázatokat várni társadalomtudományainktól - olyannyira nem, hogy a módszertani vitákban a megértő/hermeneutikai oldal képviselői egyenesen lehetetlennek tartják azokat, éppen a társadalmi jelenségek fent említett sajátosságai miatt (1Ld. ehhez: Winch, (1988) vagy Taylor, (1971).). Az oksági magyarázatok primátusának megkérdőjelezése azonban nem szükségszerüen jár együtt azzal, hogy a társadalomtudományoktól megtagadnánk mindennemú magyarázat lehetőségét. Alternatívaként a különösen a történettudományok által előnyben részesített narratív magyarázat modelljei említhetők meg, melyek relevanciája legújabban a matematikai/statisztikai alapokon nyugvó szociológiai módszertan problémái kapcsán is felmerült (1Ld. Goldthorpe, (2000;), Abell, (2004).). 


\section{Narratívák és interpretációk}

A társadalomtudományokban (leghangsúlyosabban természetesen a történettudományban) szerephez jutó narratív magyarázatok lényegében koherens történetek formájában igyekeznek számot adni valamilyen társadalmi/történelmi jelenség kialakulásáról, megváltozásáról vagy eltünéséről. A velük szemben támasztott követelmények mindenképpen megengedőbbek, mint az oksági magyarázatok érvényességét biztosító kritériumok, hiszen ezek a magyarázatok nem szükségszerü kapcsolatot tételeznek fel valamilyen $A$ és $B$ esemény között, hanem kontextusba helyezve próbálnak eseménysorként értelmezni bizonyos történéseket, jelenségeket.

Amennyiben egy társadalmi jelenségről vagy folyamatról (legyen az egy intézmény kialakulása, egy forradalom kirobbanása vagy akár egy gazdasági válság) kívánunk narratív magyarázatot adni, nem lépünk fel az általunk azonosított és lokalizált okok kérlelhetetlen szükségszerüséggel okozatukra gyakorolt hatásának igényével, pusztán igyekszünk a különbözö történéseket logikailag koherens egymásutániságukban ábrázolni. Az a narratíva, amelyik például az abszolutisztikus uralkodó által kiszabott egyre nagyobb adóterhekből, valamint az önmagát egyre inkább eltartani képes polgári réteg gondolkodásmódjának változásaiból jut el a francia polgári forradalom kirobbanásáig, nem lép fel számos olyan igénnyel, amellyel egy, ugyanerről a jelenségrôl adott, ám a társadalmi jelenségek köreiben törvények meglétét feltételező oksági magyarázat fellépni kénytelen. Mindez természetesen nagyobb támadási felületet is biztosít a narratívák magyarázóerejével kapcsolatos ellenvetéseknek. A következőkben két, a narratív magyarázatok szempontjából végzetesnek tünő ellenvetésre térek ki részletesen, majd az azokra adható válaszok után a társadalmi jelenségek fentebb leírt sajátosságainak fényében értelmezem újra a társadalomtudományos narratívák és az azokat lehetővé tevő interpretációk korlátait.

\section{Burkolt oksági magyarázat vagy egyszerü fikció? - Ellenvetések}

Az elsőként tárgyalandó ellenérv a pozitivista társadalomtudomány-koncepciók felfogásából ered, és leginkább abban az elgondolásban érhető tetten, amely a narratívákat implicit törvényeket és elméleteket tartalmazó magyarázati modellekként értelmezi. Ennek legkorábbi megfogalmazása Carl Hempel nevéhez füződik, és noha az annak alapját képező logikai pozitivista tudományfelfogás mára már meghaladott, implikációi tovább élnek a társadalomtudományok metodológiai sajátosságait tárgyaló diskurzusban. Az ellenérv röviden a következő: egy egyedi történeti/társadalmi jelenségről alkotott narratíva pusztán a felszínen tünik radikálisan különbözőnek a peremfeltételeket és általános törvényeket tartalmazó „,covering law” típusú magyarázatoktól, valójában azonban ugyanúgy sajátos partikuláris tényállásokat (peremfeltételek) egymáshoz kapcsoló biológiai, pszichológiai vagy közgazdaságtani törvényeket (általános törvények) tartalmaz, mint azok a magyarázatok, amelyekkel szemben alternatívaként kíván fellépni.

A narratíva, melyben beszámolunk például egy tőzsdekrach előzményeiről és lefolyásáról ${ }^{9}$, következtetni enged bizonyos, a keresletet és kínálatot, valamint az emberi viselkedéseket szabályozó törvények meglétére, azonban mindezt a hétköznapiságra emlékeztető nyelvhasználattal teszi. Így az az érzésünk támadhat, hogy nem törvények és elméletek segítségével kínál magyarázatot - sőt, akár úgy is gondolhatjuk, hogy egy ehhez hasonló egyedi történeti jelenséggel kapcsolatban nem is adhatunk törvényekre hivatkozó magyarázatot. Ez azonban nem több ennél az érzésnél, és amennyiben a narratíváinkat megalapozó összefüggéseket explicitté tesszük, feltárulnak a kezdeti feltételek 
és az általános törvények. Ezek a törvények pedig azért maradhatnak pusztán háttérfeltételezések, mert maguktól értetődőeknek tartjuk őket, így kevésbé lesznek reflektáltak a hétköznapi diskurzusban. Az sem lehet probléma, hogy ezek a törvények jelenleg még nem bírnak az univerzális természettörvények általános erejével - ez ugyanis nem jelentheti azt, hogy a jövőben sem fognak ilyen rangra emelkedni. ${ }^{10}$

Ezen az alapon tagadni a narratívák létjogosultságát azonban kétélü fegyvernek bizonyulhat. Mint arra Megill (2007) rámutat, az ellenérv könnyedén megfordítható, és ugyanilyen egyszerüen szembeszegezhető a pozitivista magyarázati modellel is. Értelmes ugyanis felvetni azt a kérdést, hogy a felszínen szigorú általános törvényeket tartalmazó magyarázatok nem pusztán narratívák „,csontvázai”-e valójában. Hogy ezt megválaszoljuk, nem kellene mást tennünk, mint végigmondanunk a kezdeti feltételek és általános törvények által adott magyarázatot a maga teljességében: az eredmény szintén $A$ és $B$ esemény egymásra következésének narratívája lenne. „Habár a diskurzus szintjén Hempel megfogalmazása nyilvánvalóan nem narratíva, olvasói könnyedén összerakhatják a mondatait mint narratívát, felszínre hozva a diskurzus mögötti történetet. És az olvasók valójában pontosan ezt is teszik (Megill, 2007, 70. o.). Ha pedig ezt teszik, úgy episztemikus értelemben nincs minőségi különbség a két magyarázati modell között: mindkét esetben valamilyen specifikus „miért?”-kérdésre kerestük a választ, és mindkét esetben kaptunk is erre vonatkozóan valamilyen típusú útmutatást. A magyarázat pedig éppen ugyanúgy lehet érvénytelen az egyik, mint a másik esetben: félreismerhetünk törvényeket és tévesen interpretálhatunk bizonyos jelenségeket, ezek egyike ellen sem véd meg bennünket a magyarázati modell belső logikája önmagában.

A következő, végzetesnek tünő ellenvetés a narratívaalkotással szemben nem a törvényeken alapuló magyarázattal, hanem a fiktív elbeszélésekkel hozza azokat kapcsolatba. Amennyiben egy narratíva nem egyéb, mint bizonyos, időben egymást követő események bevezetés-tárgyalás-befejezés alapú elbeszélése, úgy két különböző szempontból is támadhatóvá válik. Egyrészt minden tudományos igénnyel fellépő narratívának ügyelnie kell arra, hogy valamilyen dokumentummal vagy egyéb tárgyi bizonyítékkal összhangban legyen, azaz ne lehessen bármilyen gondolati konstruktumot a jelenségek hiteles magyarázatának színében feltüntetni. Másrészt viszont épp a belső struktúrája miatt a narratíva inherensen hamis lesz, bármennyire is igyekszik az általa elbeszélteket megalapozni: a történelemben és a társadalomban ugyanis a jelenségek nem „kezdődnek” és nem ,érnek véget”. Amennyiben pedig a narratíva ezt a látszatot igyekszik kelteni, úgy a befogadó számára nem lehet episztemikus értéke: nem megalapozott azt feltételeznünk, hogy igaz és érvényes magyarázatként szolgál. ${ }^{11}$ Szélsőséges megfogalmazásban a narratív magyarázatok tulajdonképpen nem is magyarázatok a szó tudományos értelmében, hanem csupán az őket előterjesztő és elfogadásra felkínáló kutatók élénk fantáziájának termékei. Lévén épp azok az összetevők hagyhatók figyelmen kívül az ilyen típusú magyarázatokban, melyek a tudományos, kauzális magyarázati modellekben a magyarázat érvényességét és megbízhatóságát hivatottak biztosítani, látszólag könnyedén tudománytalanként diszkreditálhatók a narratívákon alapuló magyarázat-javaslatok. Mint arra azonban Velleman (2003) rámutat, a narratív magyarázatok ereje (akár magyarázati erőként, akár egyéb típusú erőként fogjuk fel azt) nem abban rejlik, hogy a valóság jelen esetben a történeti/társadalmi valóság - bizonyos szegmenseit a megfellebbezhetetlen objektivitás igényével valamilyen modell vagy séma alá sorolják. Ezt már csak azért sem tehetik, mert a történelmi valóság objektív realitásának kérdése maga is élénk vita tárgya $^{12}$ - és amennyiben a társadalmi jelenségeket fogalmi konstitúciójuk alapján különítjük el, azok realitása sem objektív, hanem csupán interszubjektív módon lesz garantálható. Az elbeszélés-jelleg pedig, noha valóban rendelkezik befejezéssel, nem jelenti azt (és valószínüleg a magyarázat befogadója számára sem egyenértékü azzal), hogy a történelem lezárult volna azon a ponton, ahol a partikuláris kérdés tárgyalása véget ért ( $\mathrm{Vel}$ - 
leman, 2003, 19-21. o.). Ennek analógiájára egyéb társadalmi jelenségek sem szünnek meg létezni a narratíva végére - sőt, mint fentebb láthattuk, a narratíva számos esetben épp abban lehet segítségünkre, hogy bizonyos jelenségek kialakulásáról adjon számot. ${ }^{13}$

\section{Korlátozott interpretációk}

Ez természetesen még nem jelenti azt, hogy akármilyen narratíva helyesként és érvényesként lenne felfogható. Ahhoz azonban, hogy a társadalomtudományos interpretáció egy lehetséges korlátjáról szó eshessen, legalább elviekben meg kell engednünk annak lehetőségét, hogy az ilyen úton nyert ismeretek valóban ismeretek legyenek, ne csupán a képzelőerő valóságtól elrugaszkodott termékei. Ennek érdekében további korlátozásokra is szükségünk lesz, ha el szeretnénk dönteni, hogy az esetlegesen versengő interpretációk és narratívák közül melyiknek adunk hitelt a többivel szemben. Egy lehetséges megoldást

\section{Egy tudománytörténeti példa} segithet annak szemléltetésében, hogy milyen lényegi különbség adódik a természeti és társadalmi fajták konstitúciójának eltéró voltából az interpretációk megalkotása során. Gad Prudovsky (1997) azt a kérdést igyekezett megválaszolni, hogy mennyiben tulajdonithatunk bizonyos történelmi személyeknek olyan fogalmakat, melyeket azok a maguk idejében nem ismerhettek, és lingvisztikailag sem fogalmazhattak meg. A példa Alexander Koyré Gali-

lei-interpretációja, melyben Koyré olyan tömegfogalmat tulajdonit Galileinek, amellyel az nem rendelkezhetett, és amelyért késóbbi kritikusai elmarasztalták. Prudovsky szerint azonban a tehetetlenségi tömeg fogalma már implicite benne foglaltatik Galilei érvelésében, mintegy anticipálva annak késóbbi felfedezését és fogalmi kimunkálását. már Taylor $(1971,14$. o.) is kínált, amikor az emberi jelenségekkel kapcsolatos interpretációk elfogadásának függvényeként a cselekvések és azok jelentésének koherenciáját tette meg: „Ezeket az olvasatokat azonban kizárólag más olvasatokkal szemben tudjuk egyáltalán megmagyarázni vagy igazolni [...] Amennyiben valaki az ilyen típusú olvasatot nem érti vagy nem fogadja el érvényesnek, az érvelés ezen nem változtathat." Azaz az értelmezés belső koherenciája garantálná az értelmezés helyességét - és ha valaki szerint ennél többet, meggyőzőbbet kellene állítanunk felkínált értelmezésünk alátámasztására, úgy erre a felvetésre interpretatív kereteken belül nem leszünk képesek érdemben válaszolni.

Úgy vélem, ennél komolyabb megszorításokat is lehet és érdemes tenni a társadalomtudományos interpretációk érvényességével kapcsolatban. A jelenségek fogalmi természete és a fogalmaink segítségével „létrehozott" személytípusok kapcsán láthattuk, hogy azok nem pusztán a szigorú oksági magyarázatokkal kapcsolatban vetnek fel problémákat, hanem bármilyen magyarázat retrospektív érvényessége kapcsán is. Egy tudománytörténeti példa segíthet annak szemléltetésében, hogy milyen lényegi különbség adódik a természeti és társadalmi fajták konstitúciójának eltérő voltából az interpretációk megalkotása során. Gad Prudovsky (1997) azt a kérdést igyekezett megválaszolni, hogy mennyiben tulajdoníthatunk bizonyos történelmi személyeknek olyan fogalmakat, melyeket azok a maguk 
idejében nem ismerhettek, és lingvisztikailag sem fogalmazhattak meg. A példa Alexander Koyré Galilei-interpretációja, melyben Koyré olyan tömegfogalmat tulajdonít Galileinek, amellyel az nem rendelkezhetett, és amelyért későbbi kritikusai elmarasztalták. Prudovsky szerint azonban a tehetetlenségi tömeg fogalma már implicite benne foglaltatik Galilei érvelésében, mintegy anticipálva annak későbbi felfedezését és fogalmi kimunkálását. ${ }^{14} \mathrm{Ez}$ pedig tudománytörténeti jelentőséggel bír, hiszen a modern tömegfogalmunk kialakulásának kezdeteiről alkothatunk képet a segítségével. Szigorúan véve a hackingi korlátozásokat a fogalmak természetével kapcsolatban azt mondhatnánk, hogy Galilei nem dolgozhatott a tehetetlenségi tömeg fogalmával, egész egyszerüen azért, mert ilyesmi az ő korában nem létezett. A tömeg azonban természeti jelenség, és amenynyiben a dolgoknak létezik tömege, úgy azt Galilei felfedezhette volna, mint ahogyan később fel is fedezték. Így megengedhetővé válik a retrospektív fogalom-tulajdonítás, természetesen csak abban az esetben, ha nem gondoljuk azt, hogy Galilei ténylegesen tudatában volt ennek a később bekövetkezendő felfedezésnek.

Más a helyzet azonban társadalmi jelenségeinket tekintve, azokat ugyanis nem lehet anticipálni, nem várnak felfedezésre és nem találunk rájuk. Ennek következtében pedig egyetlen olyan, időben vagy térben távoli társadalmi berendezkedéssel kapcsolatban sem számíthatnak legitim interpretációknak azok, amelyek olyan fogalmi kerettel dolgoznak, mely a vizsgált társadalom tagjainak nem állhatott rendelkezésére. Egy idegen civilizáció hagyományainak például nem adhatjuk olyan interpretációját, amely szerint vallási rituáléikkal a fiatalkorú bünelkövetők számának csökkenését célozzák, ha a vizsgált társas kontextusban a „fiatalkorú bünelkövető” fogalma nem létezik. Épp azért nem, mert nem lehet számítani arra, hogy a közeljövőben felfedezik azt, vagy hogy az implicite már kialakult bennük, pusztán a megfogalmazása várat magára. A megfogalmazás ebben az esetben ugyanis a létezés előfeltétele, a kettő elválasztása pedig a narratívánk intelligibilitását aknázná alá.

\section{Konklúzió}

A fentiekben a társadalomtudomány által vizsgált jelenségek természetét, illetve az azokról adott interpretációk és az azokkal kapcsolatban konstruált narratívák érvényességét vizsgálva azt igyekeztem kimutatni, hogy társadalmi jelenségeink fogalmi természete két szempontból is alapvető hatással van (avagy annak ideális esetben hatással kellene lennie) tudományos vizsgálódásainkra. Egyrészt segítségével megindokolható, hogy a természettudományos módszertani megfontolások miért nem alkalmazhatók fenntartások nélkül a társadalmi jelenségek vizsgálatára, másrészt pedig annak is határt szab, hogy ezek a jelenségek milyen interpretációs keretben értelmezhetőek egyáltalán. Ez utóbbi korlátot azért is különösen fontos hangsúlyozni, mivel gyakran érik az interpretatív társadalomtudományokat „mindent szabad” típusú vádak. Ezekre éppen az ad alapot, hogy amennyiben a társadalom területén történő vizsgálódásainkat nem szabályozzák törvények és elméletek, úgy látszólag nincs, ami garantálná egy elfogadásra ajánlott interpretáció érvényességét. Ennyire viszont nem lehet megengedő az interpretatív társadalomtudomány, és a jelenségek fogalmi természetéből adódó korlátok határt is szabhatnak az értelmezések látszólag tetszőleges tartalmának. 


\section{Irodalomjegyzék}

Abell, P. (2004): Narrative Explanation: An Alternative to Variable-Centered Explanation? Annual Review of Sociology, 30. 287-310. DOI: 10.1146/annurev.soc.29.010202.100113

Beebee, H. és Sabbarton-Leary, N. (2010, szerk.): The Semantics and Metaphysics of Natural Kinds. Routledge, London. DOI: 10.4324/9780203852330

Bhaskar, R. (1979): The Possibility of Naturalism. Routledge, London.

Campbell, J. K., O’Rourke, M. és Slater, M. H. (2011, szerk.): Carving Nature at its Joints: Natural Kinds in Metaphysics and Science. The MIT Press, Cambridge/MA.

DOI: 10.7551/mitpress/9780262015936.001.0001

Carr, D. (2008): Narrative Explanation and Its Malcontents. History and Theory, 47. 1. sz. 19-30. DOI: 10.1111/j.1468-2303.2008.00433.x

Cooper, R. (2004): Why Hacking is Wrong about Human Kinds. The British Journal for the Philosophy of Science, 55. 1. sz. 73-85. DOI: 10.1093/ bjps $/ 55.1 .73$

Davidson, A. (1990): Closing up the Corpses: Diseases of Sexuality and the Emergence of the Psychiatric Style of Reasoning. In: Boolos, G. (szerk.): Meaning and Method - Essays in Honor of Hilary Putnam. Cambridge University Press, New York. 295-326.

Demeter Tamás (2008): Mentális fikcionalizmus. Gondolat, Budapest.

Flyvbjerg, B. (2001): Making Social Science Matter. Cambridge University Press, New York. DOI: 10.1017/cbo9780511810503

Foucault, M. (1979) Discipline and Punish - The Birth of the Prison. Knopf Doubleday Publishing, New York.

Goldstein, L. J. (1976): Historical Knowing. University of Texas Press, Austin.

Goldthorpe, J. H. (2000) On Sociology - Numbers, Narratives, and the Integration of Research and Theory. Oxford University Press, New York.

Hacking, I. (1986): Making up People. In: Heller, T. (szerk.): Reconstructing Individualism. Stanford University Press, Stanford, CO. 222-236.

Hacking, I. (1995a): Rewriting the Soul. Princeton University Press, Princeton.

Hacking, I. (1995b): The Looping Effects of Human Kinds. In: Sperber, D., Premack, D. és Premack, A. (szerk.): Causal Cognition. An interdisciplinary Approach. Oxford University Press, Oxford.

Haddock, A. (2002): Rewriting the Past: Description and its Consequences. History of the Human Sciences, 32. sz. 3-24. DOI: 10.1177/004839310203200101
Hawley, K. és Bird, A. (2011): What are Natural Kinds? Philosophical Perspectives, 25. 1. sz. 205 221. DOI: 10.1111/j.1520-8583.2011.00212.x

Hempel, C. G. és Oppenheim, P. (1999): A tudományos magyarázat logikája. In: Forrai Gábor és Szegedi Péter (szerk.): Tudományfilozófia - Szöveggyüjtemény. Áron, Budapest. 109-129.

Leudar, I. és Sharrock, W. (2002): Indeterminacy in the Past? History of the Human Sciences, 15. sz. 95-115. DOI: 10.1177/0952695102015003169

Leudar, I. és Sharrock, W. (2003) Changing the Past? History of the Human Sciences, 16. sz. 105-121. DOI: 10.1177/09526951030163006

Megill, A. (2007): Historical Knowledge, Historical Error. Chicago University Press, Chicago.

Mink, L. O. (1987): Historical Understanding. Cornell University Press, Ithaca - New York.

Prudovsky, G. (1997): Can We Ascribe to Past Thinkers Concepts They Had No Linguistic Means to Express? History and Theory, 36. 1. sz. 15-31. DOI: 10.1111/0018-2656.00002

Putnam, H. (1975): The Meaning of 'Meaning'. In: uő: Mind, Language and Reality. Cambridge University Press, Cambridge. 215-271. DOI: 10.1017/ cbo9780511625251

Roth, P. A. (2002): Ways of Pastmaking. History of the Human Sciences, 15. sz. 125-143. DOI: 10.1177/0952695102015004684

Roth, P. A. (2012): The Pasts. History and Theory, 51. 3. sz. $313-339$.

DOI: $10.1111 / \mathrm{j} .1468-2303.2012 .00630 . x$

Sayer, A. (2010): Method in Social Science: A Realist Approach. Routledge, London.

Sivadó Ákos (2010): Fajtáink eredete. Magyar Filozófiai Szemle, 1. sz. 46-58.

Taylor, Ch. (1971): Interpretation and the Sciences of Man. The Review of Metaphysics, 25. 1. sz. 3-51.

Velleman, J. D. (2003): Narrative Explanation. The Philosophical Review, 112. 1. sz. 1-25. DOI: 10.1215/00318108-112-1-1

Weber, M. (1987): Gazdaság és társadalom. Közgazdasági és Jogi Könyvkiadó, Budapest.

Wendt, A. (1999): Social Theory of International Politics., Cambridge University Press, Cambridge. DOI: $10.1017 /$ cbo9780511612183

White, H. (1987): The Content of the Form: Narrative Discourse and Historical Representation. The Johns Hopkins University Press, Baltimore.

White, H. (1997): A történelem terhe. Osiris, Budapest.

Winch, P. (1988): A társadalomtudomány eszméje és viszonya a filozófiához. Akadémiai, Budapest. 


\section{Jegyzetek}

${ }^{1}$ Már a szociológia 19XIX. század végi klasszikusa, Max Weber (1987, 37-38. o.) iés ekképp fogalmazta meg tudományterülete fö feladatát: „A szociológia $[\ldots]$ az a tudomány, amely a társadalmi cselekvés értelmező megértésére, és ezen keresztül a cselekvés menetének és hatásainak oksági magyarázatára törekszik." Weber (1987), 37-38.

${ }^{2}$ A természeti fajták létével és metafizikájuk kérdéseivel kapcsolatban bőséges szakirodalom áll rendelkezésre az elmúlt évtizedekböl. A legfrissebbek közül érdemes megemlíteni a Beebee és Sabbarton-Leary által 2010-ben, illetve. a Campbell, O’Rourke és Slater által 2011-ben szerkesztett átfogó szöveggyüjteményeket, valamint Hawley és Bird (2011) tanulmányát.

${ }^{3}$ Ennek kapcsán jogosan jegyzi meg Cooper (2004), hogy amennyiben pusztán a mesterséges előállíthatóságot tekintenénk a társadalmi fajtákat a természetiektől alapvetően elkülönítő sajátosságnak, úgy mindössze „,nem különösebben hasznos” természeti fajtákat kapnánk eredményül.

${ }^{4}$ A természeti fajták klasszifikálásának nehézségeivel Sivadó (2010) foglalkozik részletesen.

${ }^{5}$ Ld. ehhez: Winch ((1988), 115-123. o.). A társadalmi és a mentális jelenségek között ebböl a szempontból hasonlóságok fedezhetők fel - az emellett szóló érveket ld. Demeter ((2008), 102-114. o.).

${ }^{6}$ Minderről részletesen ld. Hacking ((1995a)). A kategorizáltak internetes jelenlétére példa többek közt a http://www.angelfire.com/wv/mpdrules/ oldala.
${ }^{7}$ Természetesen bizonyos külső körülmények fennállása mellett. Amennyiben valakinek az élete múlik azon, hogy befektet-e avagy sem, a bizalom megléte vagy hiánya veszít fontosságából.

${ }^{8}$ A társadalomtudományos konceptualizáció tudományos magyarázatokra tett hatásáról ld. Sayer ((2010)).

${ }^{9}$ A példa Hempel és Oppenheim (1999) írásából származik, ld. Hempel-Oppenheim (1999).

${ }^{10}$ A tudományfejlődés mint a potenciális társadalmi törvények felfedezésének motorja számos szempontból problematikus. A fentebb vázolt sajátosságok is megkérdőjelezik ennek legitimitását, részletes kritikájához ld. Flyvbjerg (2001), 25-37. o.).

${ }^{11}$ A narratívák szükségszerüen hamis voltának problémái a legélesebben Hayden White írásaiban jelennek meg; ld. ehhez különösen White (1987), magyarul White (1997).

${ }^{12}$ Ennek kezdeteihez ld. Goldstein (1976) és Mink (1987), újabb tárgyalásához pedig Haddock (2002), Leudar és Sharrock $(2002,2003)$, valamint Roth (2002, 2012).

${ }^{13}$ Egyéb, a narratív magyarázatokkal szemben megfogalmazott bírálatok részletes tárgyalásához ld. Carr (2008)

${ }^{14}$ Prudovsky (1997), 25-26. o.). A gondolatmenet részletes rekonstrukcióját ld. Roth (2013), 23-25. o.) 